\title{
Pigmented dermatofibrosarcoma protuberans
}

Pigmented dermatofibrosarcoma protuberans
(Bednar Tumor)
先天性の萎縮斑として初発したと思われる小児例
三原 一郎* 斎藤 秀剛* 矢田 義幸*—

\section{Summary}

生下時より存在していたと思われる背部の萎縮斑上に多発性に生じたpigmented dermatofibrosarcoma protuberansの女児例を報告した。組織学的には線維芽細胞様細胞が storiform patternを呈し密に増殖し, 処々に担色素細胞が混在した。担色素細胞は, 免疫 組織学的，電顕的所見よりメラノサイトと同定されたが，腫瘍の主たる構成細胞は種々の 抗体に反応せず，電顕的にもその起源を支持する程の所見は得られなかった。腫瘍の母地 となった，萎縮斑部の組織像はneurofibromaに類似はしていたが，S-100蛋白陰性で，腫 瘤部との移行像からも同一腫瘍と考えるのが妥当と思われた。

\section{緒言}

Bednar ${ }^{1)} よ り$ storiform neurofibromaとし て報告された特異な腫瘍は, 今日では担色素細 胞の混在以外は臨床的, 組織学的, 免疫組織学 的に dermatofibrosarcoma protuberans (DFSP) と異なる点はないとして, DFSPの一 覀型とみなし, pigmented dermatofibrosarcoma protuberans (pigmented DFSP) とし ての報告が一般的である。しかし，その起源に 関しては未だ一致した見解はなく，異論の多い ところである。

最近，われわれは生下時からと思われる萎縮 斑状に巨大腫瘤および多発性結節を形成すると いう興味ある臨床像を呈し, 組織学的には DFSPの像に担色素細胞が混在し pigmented

* Ichiro MIHARA, Hidetake SAITO, Yoshiyuki YADA，東京慈恵会医科大学青戸病院皮膚科
DFSP と診断した女児例を経験したので報告す る。

\section{症例}
患 者：8歳, 女児。
初 診：昭和 62 年 1 月 12 日

家族歴, 既往歴 : 特記事項なし

現病歴 : $1980 \mathrm{~g} の$ 未熟児として出生。生後45 日目に退院後, 母親が初めて右背部の手拳大, 毛細血管が透過できる萎縮斑に気付いた。生下 時にこの萎縮斑が存在したかどうかは確認がと れていない。3 歳頃より, 萎縮斑内に血腫様隆 起病変が出現し, 近医で 2 回ほど穿刺処置を受 けたが，その後紫色の丘疹として固定し，この 丘疹は当院来院まで漸次增大し続けたという。 この間とくに医療施設を受診していない。5 歳 頃には中央部の腫瘍病変の周囲に丘疹, 結節が 出現し始め, 増数した。

現 症：上背部右側に $13 \mathrm{~cm} \times 9 \mathrm{~cm}$ 大の淡紅色, 
一部暗紫色を呈するほぼ楕円形の萎縮斑があり, その中央に $40 \times 30 \mathrm{~mm}$ 大, ドーム状に隆起寸る腫 瘍が存在した(図 1 )。腫瘍は全体に暗紅色であ るが，基底部では暗紫色調を呈し，境界は極め て明瞭で皮下とは癒着せず，弾性硬であった。 また，腫瘍の周辺，萎縮斑内に限局して， $2 \mathrm{~cm}$ 大位までの一部は表皮より隆起する，皮下結節 を数個触れた。

その後, 患者が来院せず初診後約 10 力月経た 時点では中央部の腫瘍は $8 \times 8 \mathrm{~cm}$ 大にまで増殖 した。

検查所見：血液学的, 生化学的, 免疫学的検 查に異常を認めない。

病理組織学的所見：腫瘤は真皮浅層より皮下 脂肪織にかけて広がる紡錪形細胞の稠密な濔漫 性増殖よりなる(図 2)。被覆表皮は圧排され薄 く萎縮性である。腫瘍の辺縁は圧排された結合 織で極めて明瞭に境されているが，被膜は有し

(45)

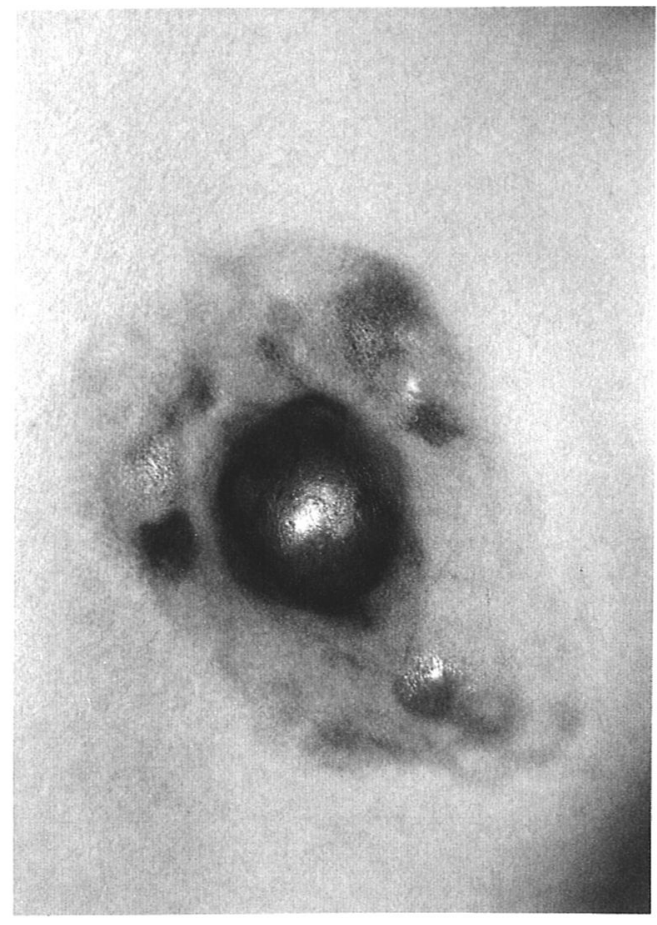

図 1 .
ない。腫瘍辺縁では, 細胞の密度は低下する傾 向にある。紡鍾形の腫瘍細胞は短かい束をなし て種々の方向に錯走し， storiformあるいは cartwheel pattern と呼ばれる特徵的な配列を 示す。個々の腫痬細胞は紡錘形あるいは楕円形 の核と, 細長く伸びた好酸性の胞体を有し，互 いの境界は不鮮明である。核異型にはそしく， 核分裂像も稀である。

この稠密な紡錘形細胞の増殖病変内に点在性 に褐色あるいは黒褐色色素に富む不規則な形態 の細胞が観察される(図 3 )。この色素は Fontana-Masson染色で黒染し, Berlin blue染 色陰性で，過マンガン酸カリで漂白され，メラ ニン色素と同定される。

萎縮斑における組織所見は真皮中層から脂肪 織にかけて紡錘形の線維芽細胞様細胞がほぼ表

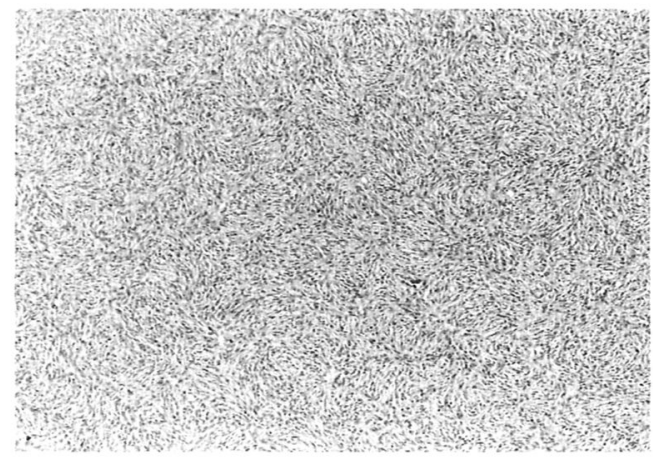

図 2 .

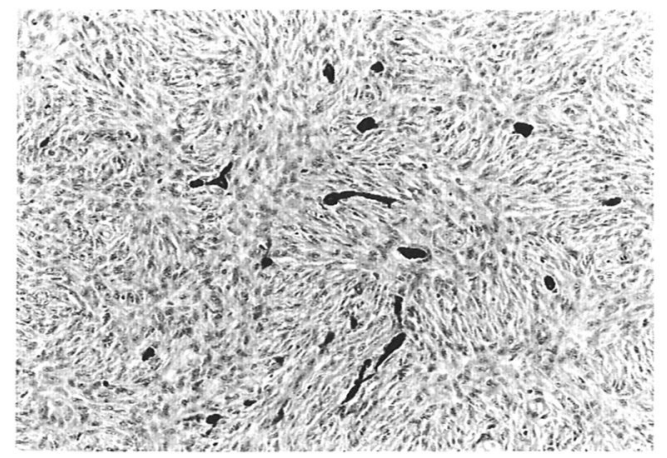

図 3 . 
皮と平行に増生するが,ここではstoriform patternはみられず，細胞密度は腫瘤形成部に比し 低い（図 4 )。

免疫組織学的所見: S-100蛋白, neuron specific enolase (NSE), $\alpha_{1}$-antichymotrypsin, lysozyme, desminの局在を酵素抗体法を用い

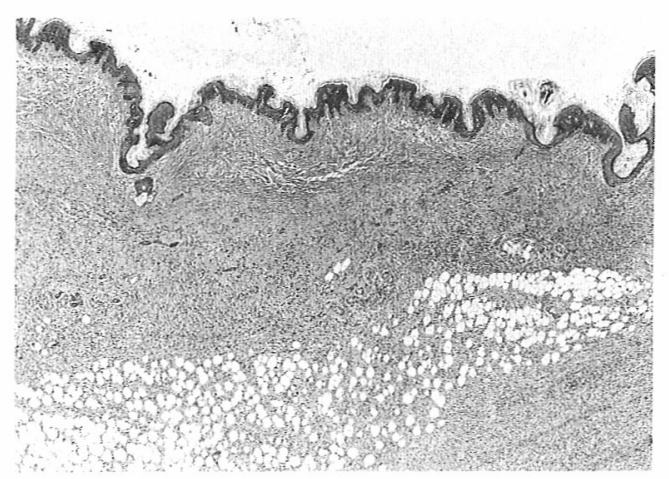

図 4 .

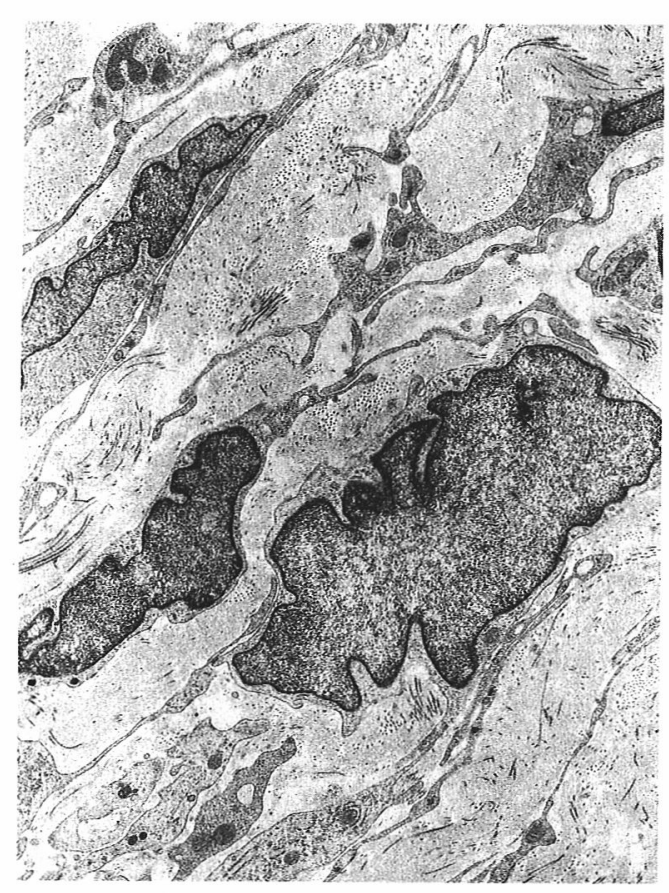

図 5 .
て検討した。担色素細胞に対する反応を明瞭に するため，漂白標本に対しても上記抗体を反応 させ検討した。腫瘍の主体をなす非担色素細胞 では上記全ての抗原の局在は証明できなかった。 一方, メラニン含有細胞では, 漂白標本におい てS-100蛋白陽性で，NSEが一部に弱陽性であ った。

電顕的所見：腫瘍の主体を占める線維芽細胞 様細胞は核辺の heterochromatinを有寸る辺縁 凹凸不整長核を有し，胞体は細胞核下に多い pinocytic vesicleに富み，概してミトコンドリ ア，粗面小胞体，ゴルジ装置にそしく，微細顆 粒状の胞体を呈する（図 5 )。基底膜は一部で未 発達ながら観察されたが，全体的にはその形成 は乏しい。

これら増殖細胞間にメラノゾームに富む類似 の形態をもつ細胞が介在する。メラノゾームは 殆どが350-500nm内外のものでIV型成熟型で, これは高度にelectron denseの微細顆粒の長円 形集積で，これらは互いに癒合してcomplexを 形成するものもある。また，II III型メラノゾー ムは僅かにみられるのみである(図6)。これら 2 種の細胞間に直接の移行像は認められない。

\section{治療および経過}

患者が 8 歳，女児であることを考慮し，植皮 術は避け分割縫縮術で治療することとし，まず は大きな腫瘤と周囲の小結節を取れるだけ一塊 にして筋膜上で切除し，単純縫縮した。さらに， 術後 4 力月に, 残存する結節を数個筋膜上で切 除した。現在, 初回の手術から約 10 力月経過し ているが萎縮局面は残存するも腫瘤の形成はみ られていない。いずれ，全摘の予定である。

\section{考按}

1957年Bednar ${ }^{1)}$ は, 多数の spindle cell neoplasmを組織学的に検討した際，いわゆるstoriform patternを呈した 9 症例（内 5 例が担色素 


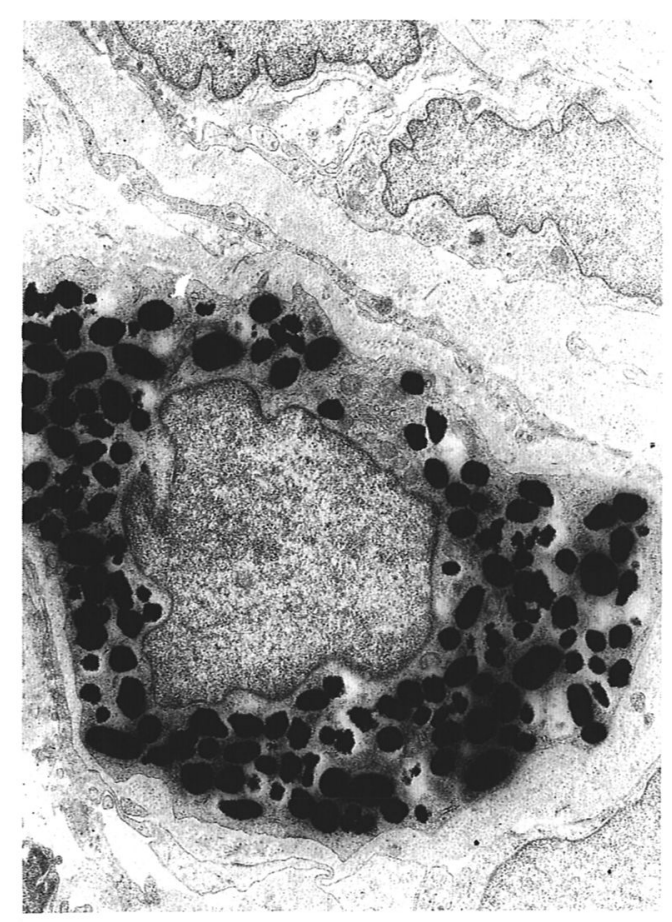

図6.

細胞を混在した）を総括し，これらを，1）腫 瘍細胞がシュワン細胞に類似する，2）腫瘍細 胞内にメラニン含有細胞が混在する， 3 ) storiform patternはときに青色母斑にみられる，と いう根拠のもとにこれらの腫瘍は神経原性のも のでneurofibromaの一亜型と考え storiform neurofibromaとして報告した。

以後, 現在まで担色素細胞の混在を伴った同 様の症例は30数例報告されている年 6)。しかし， その名称に関してはメラニン含有細胞の混在以 外, storiform neurofibromaとDFSPとに, 臨床 的, 組織学的, 免疫組織学的に相違点を見出す ことは困難でむしろ同一疾患とみなせるもので あること, storiform neurofibromaは過去の報 告例ではすべてS－100蛋白陰性で，ほとんど常 に陽性所見をとるneurofibroma とは応性が 異なり, neurofibromaとは起源の異なる腫瘍で うことより, Bednarの報告したstoriform neurofibromaはDFSPの一つの variant とし, pigmented DFSP とするのが今日一般的である゙け6)
しかし, pigmented DFSPと通常のDFSP間に はその再発率, 転移率には多少の差が認めら れ6)，また電顕上での差異も指摘されており7同 一起源の腫瘍とすべきかどうかには, さらに症 例の蓄積, 検討が必要であろう。

自験例は, 組織像におけるstoriform pattern を示す紡錘形線維芽細胞様細胞の増殖と, 担色 素細胞(メラノサイト)の混在より, pigmented DESP (storiform neurofibroma, Bednar tumor)として問題ないと思われたが, 過去の報 告例とは異なった以下の興味深い所見が見出さ れた。

1）生下時にはすでに, 本腫瘍が萎縮局面と して存在していた。

2 ）この萎縮局面より多発性に腫瘤が生じ, その一部は巨大な腫瘤形成に至った。

$3) こ の$ 萎縮局面の組織像は一見 neurofibroma様であったが，S-100蛋白染色陰性で, 腫瘤形成部と同様の染色態度を示した。

4) 腫瘤自体は極めて境界明瞭で，通常の DFSPのような皮下脂肪織への浸潤性増殖を示 さなかった。

すなわち，自験例は先天性に存在したと思わ れる萎縮局面を母地として生じてきた腫瘍であ るという点が最も興味をひいた。

萎縮局面は組織学的にはneurofibromaに類 似していたが, 腫瘤形成部の細胞とは移行があ ク，また種々の染色態度も腫瘤部と同様である ことより，基本的には同一の腫瘍と考えたい。 なお，このような臨床像を呈した症例の報告は みあたらない。

DFSPの起源に関しては, 線維芽細胞起源 説 $^{8)}$, 組織球起源説 9 , 神経起源説 ${ }^{10)}$ などある が, pigmented DFSPにおけるメラノサイトの 混在に関しては，メラノサイトが腫瘍そのもの であるという考え方と, メラノサイトは腫瘍に 巻き込まれて反応性に増殖しているに過ぎない という，2通りの考え方ができよう。前者の考 えは本腫瘍の神経起源説を支持するが, ヒトの 背部には元来dermal melanocyteが存在すると 
の考えもあり，線維組織球系腫瘍が既存のdermal melanocyteを伴って増殖したという考え もあながち否定はできまい。自験例では免疫組 織学的手技や，電顕所見から本腫瘍の起源を示 唆するような所見は見い出せえなかったが，先 天性の病変でかつメラノサイトが混在したとい う所見は，自験例の母斑的性格を示唆し興味深 く思われた。

\section{文献}

1) Bednar, B. : Storiform neurofibromas of the skin, pigmented and nonpigmented. Cancer, 10 : $368-376,1957$.

2) Nishio, K., Koda, H. : A case of storiform neurofibroma. J. Dermatol., 2: 143-148, 1975.

3) Santa-Cruz, D. J., Yates, A. : Pigmented storiform neurofibroma. J.Cutan. Pathol. 4: 8-13, 1977.

4) Miyamoto, Y., Morimatsu, M., Nakashima, T. : Pigmented storiform neurofibroma. Acta Pathol. Jpn. 34: 821-826, 1984.

5) Nakamura, T., Ogata, H., Katsuyama, T.: Pigmented dermatofibrosarcoma protuberans:
Report of two cases as a variant of dermatofibrosarcoma protuberans with partial neural differentiation. Am.J.Dermatopathol., 9: $18-$ 25, 1987.

6) Dupree, W. B., Langloss, J. M., Weiss, S. W. : Pigmented dermatofibrosarcoma protuberans (Bednar tumor): A pathologic, ultrastructural, and immunohistochemical study. Am.J.Surg. Pathol., 9: 630-639, 1985.

7）神保孝一, 高橋博之, 及川修, 石田修, 加藤光子： 神経皮膚症候群における神経㯕由来の腫瘍, 厚生 省特定疾患神経皮虔症候群調查研究班昭和 59 年 度研究報告書, p178，1984

8) Escalona-Zapata, J., Fernandoz, E. A., Escuin, F. L. : The fibroblastic nature of dermatofibrosarcoma protuberans. A tissue culture and electron miroscopic study. Virchows Arch. Pathol. Anat. 391: 165-175, 1981.

9) Ozzello, L., Halmes, J. : The histiocytic nature of dermatofibrosarcoma protuberans. A tissue culture and electron microscopic study. Am.J. Clin.Pathol.65: 136-148, 1976.

10) Hashimoto, K., Brownstein,M. H., Jacobiec,F. A. : Dermatofibrosarcoma protuberans. A tumor with perineural and endoneural cell features. Arch.Dermatol. 110: 874-885, 1974. 